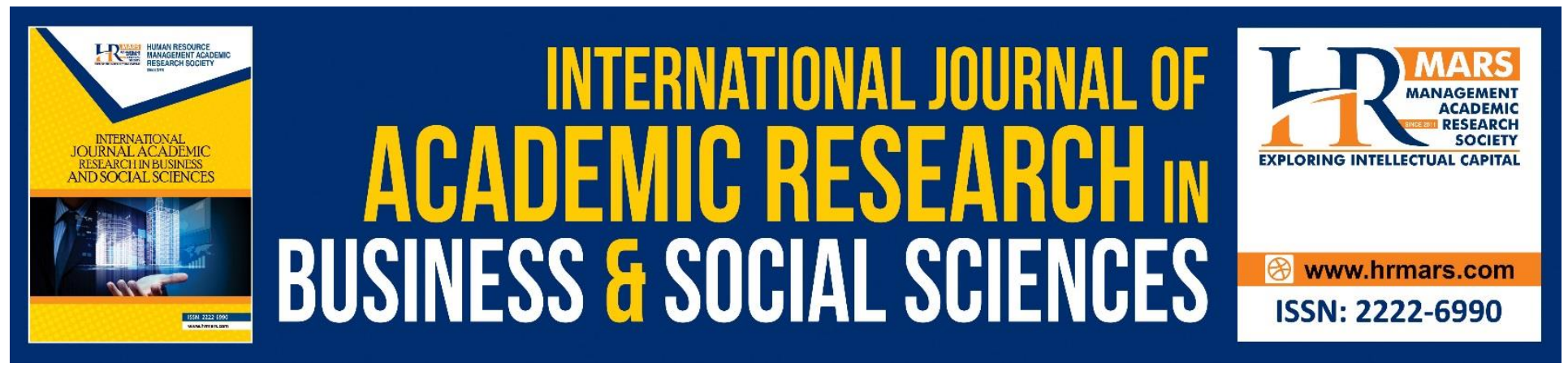

\title{
Motivational factors those Enforce Business students for Become Entrepreneur: A Case Study of Sindh, Pakistan
}

Ikramuddin Junejo, Ahmed Ali, Anosha Mustaque, Rehmat Iqbal

To Link this Article: http://dx.doi.org/10.6007/IJARBSS/v8-i9/4658

DOI: $\quad 10.6007 /$ IJARBSS/v8-i9/4658

Received: 02 August 2018, Revised: 27 August 2018, Accepted: 29 Sept 2018

Published Online: 15 October 2018

In-Text Citation: (Junejo, Ali, Mustaque, \& Iqbal, 2018)

To Cite this Article: Junejo, I., Ali, A., Mustaque, A., \& Iqbal, R. (2018). Motivational factors those Enforce Business students for Become Entrepreneur: A case study of Sindh, Pakistan. International Journal of Academic Research in Business and Social Sciences, 8(9), 835-850.

Copyright: (C) 2018 The Author(s)

Published by Human Resource Management Academic Research Society (www.hrmars.com)

This article is published under the Creative Commons Attribution (CC BY 4.0) license. Anyone may reproduce, distribute, translate and create derivative works of this article (for both commercial and non-commercial purposes), subject to full attribution to the original publication and authors. The full terms of this license may be seen at: http://creativecommons.org/licences/by/4.0/legalcode

Vol. 8, No. 9, September 2018, Pg. 835 - 850

Full Terms \& Conditions of access and use can be found at http://hrmars.com/index.php/pages/detail/publication-ethics 


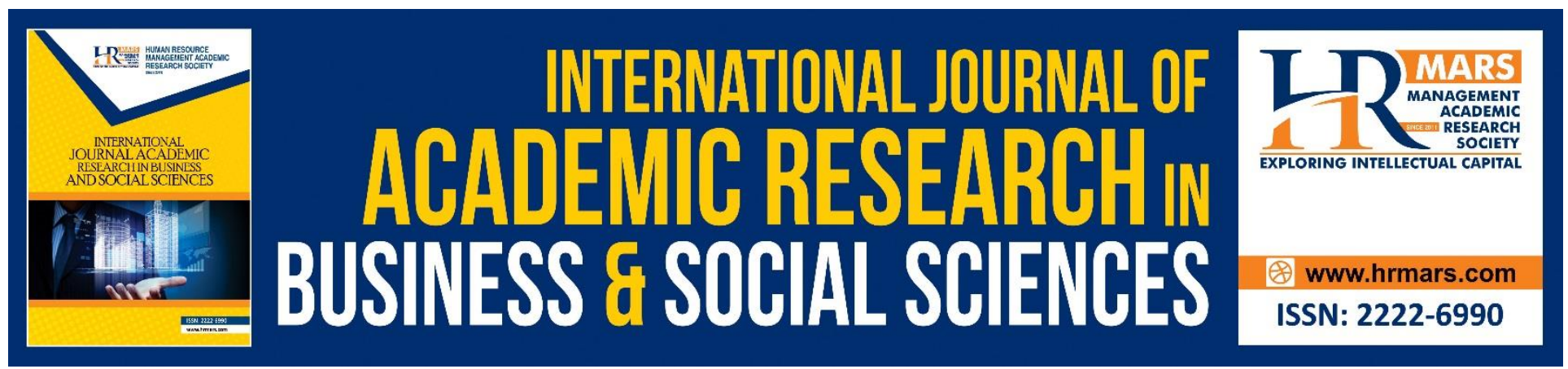

\title{
Motivational factors those Enforce Business students for Become Entrepreneur: A case study of Sindh, Pakistan
}

\author{
Ikramuddin Junejo \\ Lecturer, Department of Management Sciences, SZABIST Hyderabad campus, Sindh, Pakistan
}

\begin{abstract}
Ahmed Ali
MBA Student, Department of Management Sciences, SZABIST Hyderabad campus, Sindh, Pakistan
\end{abstract}

Anosha Mustaque

MBA Student, Department of Management Sciences, SZABIST Hyderabad campus, Sindh, Pakistan

\section{Rehmat lqbal}

MBA Student, Department of Management Sciences, SZABIST Hyderabad campus, Sindh, Pakistan

\begin{abstract}
Purpose: Pakistan, a least favourable country for the business with most of its population is youth. $63 \%$ of Pakistan's youth is under the age of 25 . Though the country on one hand is producing a huge number of business graduates every year while on other hand economic condition of country is declining continuously, this situation can only be handled through motivating youth towards entrepreneurship.
\end{abstract}

Design / Methodology / Approach: This research was conducted through primary data; the data has been collected with the help of adopted questionnaire and the total numbers of respondents for this study were 330 final year students of BBA \& MBA from Karachi and Hyderabad. The variables such as business graduates to become entrepreneur, intrinsic rewards, extrinsic rewards, autonomy, and family security and change management were studied. For the analysis, various statistical techniques have been applied such as reliability analysis and multiple regressions for the conclusion of this study. Findings: All the above studied variables are found significant and positive except change management on business graduate to become entrepreneur after graduation.

Originality / Value: The previous studies in the literature focus personality characteristics, constraints and issued faced by young entrepreneur in Pakistan. This study will emphasize the impact of 
INTERNATIONAL JOURNAL OF ACADEMIC RESEARCH IN BUSINESS AND SOCIAL SCIENCES

Vol. 8, No. 9, Sept. 2018, E-ISSN: 2222-6990 @ 2018 HRMARS

education to entrepreneur, according to our limited knowledge the business education with respect to entrepreneur has not studied before this.

Keywords: Entrepreneurship, Exogenous Factors, Endogenous Factors

\section{Introduction}

\section{Entrepreneurship}

Entrepreneur is an individual who explores new ideas, services, products and business Frederick (2016) .In the positive economy position, social value can be increased with help of entrepreneurship because it generates jobs and income Kelly (2010). It has been practically observed that the entrepreneurship topic is the focus or discussion point by both research scholars and policy makers for the last couple of years. The key reason can be entrepreneurs enhance the economic development via introducing new ideas of doing business and capital formation cannot be ignored in terms great rate of return on investment. It not only provides jobs opportunities to individuals but also increase competitiveness into economy Reynolds (1987) and Zahra (1999) There is also positive relationship between entrepreneurship and economic growth in long run (Poh kam Wong, 2005).

\section{Entrepreneurship in Pakistan}

Pakistan ranked 138 out 189 countries among world in terms of doing business so, it is clearly indicated that Pakistan is least favourable country for doing business. The number of unexplained reasons can be responsible for such ranking.

Pakistan is one leading emerging economy among the world, the 6th largest country in terms of population and now international investors are considering Pakistan as a good or less risky in terms of business failure. China and other Asian countries interest through huge in the history of Pakistan FDI (CPEC) leads to create number of opportunities for entrepreneurs to invest and earn handsome return on their investment has been observed.

Unfortunately, the resources in Pakistan are not utilized properly and majority of natural resources are not explored for better economic development into country, research scholars and policy makers are claiming that once proper entrepreneur incubation centres will be established than this huge gap can be filled. Currently total contribution of entrepreneurship businesses is only $07 \%$ in the GDP of Pakistan Mustafa (2003). Yet, we are unable to define this less contribution of entrepreneurship in GDP of Pakistan but an idea or thoughts may lead this is due to lack of effective market analysis, traditional businesses and inadequate market knowledge etc.

The number of individuals who have new ideas for doing business but due to lack of capital for investment and less or no support by financial institutions concern of security or guarantee against loan.

\section{Entrepreneurship and Academia}

Due to global economic challenges and dynamics of technology the higher education is no more guarantee of employment Collins (2004). Most universities invest handsome amount for promoting entrepreneurship culture among students the entrepreneurship incubation centres are best example and in Pakistan LUMS Lahore started in1990, followed by IBA-Karachi and now number 
of public and private higher education institutes/universities are introducing incubation centres at their universities.

Pervious literature reviews also link between entrepreneurship and education Galloway (2002), Gorman (1997), Henderson (2000), Kolvereid (1997), so higher formal education enhance the intention among graduate to become entrepreneur. But, mass development of higher education system in Pakistan couldn't address the unemployment problem among university graduates become too serious and this leads to down morality of number of stakeholders which includes parents, students, government and social institutes etc.

These business graduates not only engage themselves to start up new business ventures but also support to government through decreasing unemployment level into country.

Many students can contribute to the economic development and economic growth after they graduate especially in business not only as a salary based worker but as entrepreneur. According to one of researcher Westhed (2005), the entrepreneurship educations can contribute for entrepreneurship development in the following various ways:

- To develop trained and skilled business graduates for introducing new product and services

- To reduce the ratio of business failures due internal and external constraints

- To analyse new business ventures into new market through business start up

- To encourage financial institutions for understanding and support entrepreneurship programs

\section{Problem Statement}

The previous studies in the literature focus personality characteristics Bonnett and Furnham (1991), Brockhaus (1980), Johnson (1990) and Hasnu (2016), constraints and issued faced by young entrepreneur in Pakistan. Kavitha Raman (2008) motivational factors that enforce women to become entrepreneur in Malaysia.

It has been observed that enrolment ratio in business schools in Pakistan is much higher than employment opportunities, which is producing more business graduates with less job opportunities.

\section{Research Gap}

There are two main gaps that have been identified in the literature and previous researches. The first gap is lesser focus on the rural students and graduates. Global Entrepreneurship monitor (GEM) and Panel study of entrepreneurial Dynamics (PSED) suggest that the focus of research in this area is generally based on urban sampling. Little efforts have been done to explore in depth the rural sample of the country. The second gap is with respect to lesser number of business graduates opting for entrepreneurship. Previous researches have not elaborately discussed the reasons and factors due to which business graduate do not venture into entrepreneurship and prefer to work as an employee and do job.

\section{Theoretical and contextual Contribution of the Study}

In order to be successful entrepreneurial students should develop qualities for risk-taking and end up task with visionary perspective (Murneiks, 2014). The educational background is considered an important factor for entrepreneurial motivation Kuratko (2005), McCrea (2010). The entrepreneurial mind should be set at very young age and formal education will help to graduates for developing 
necessary skills and think out of box approach could be developed among students (Hazzouri, 2014). Understanding this approach, entrepreneur become an integral part of tertiary education in Pakistan. However, after completion of degree program may students hardly prefer to be entrepreneurs.

There are some questions that need to be addressed for entrepreneurial activities for designing the overall academic progress in the field of entrepreneurship. In this we are analysing key motivational factors that influence Business graduate in Sindh to become entrepreneur after completion of their degree program. The study is significant from many perspectives. At first the research would fill the already existing gap in the literature. The research would be of significant use for the Governmental organizations to understand and identify the factors through which entrepreneurship could be further progressed in the country. The report would be of significant use to the social organizations and NGO's and would help them in assessing the perspective of the youth of the country and take initiatives for their positive contribution in the society. The report could also be termed significant for businesses and corporate organizations to understand the dynamics of educational sector of the country and create environment in which they may receive a more diverse and intellectually superior workforce.

\section{Research Aim and Objectives}

I. To find the significant impact of motivational factors (Intrinsic rewards, Extrinsic Rewards, Autonomy, Family security and Change management) on business graduates to become entrepreneur in Sindh, Pakistan.

\section{Research Questions}

Following are the research questions of the study:

1. What is the significant impact of motivational factors (Intrinsic rewards, Extrinsic Rewards, Autonomy, Family security and Change management) on business graduate to become entrepreneur in Sindh, Pakistan?

\section{Research Hypotheses}

Based on the objectives of the research thesis, following are the proposed hypotheses:

$\mathbf{H}_{1}$ : There is significant impact of intrinsic rewards on business graduate to become entrepreneur in Sindh, Pakistan.

$\mathrm{H}_{2}$ : There is significant impact of extrinsic rewards on business graduate to become entrepreneur in Sindh, Pakistan

$\mathrm{H}_{3}$ : There is significant impact of autonomy on business graduate to become entrepreneur in Sindh, Pakistan

$\mathrm{H}_{4}$ : There is significant impact of family security on business graduate to become entrepreneur in Sindh, Pakistan

$\mathbf{H}_{5}$ : There is significant impact of change management on business graduate to become entrepreneur in Sindh, Pakistan 
INTERNATIONAL JOURNAL OF ACADEMIC RESEARCH IN BUSINESS AND SOCIAL SCIENCES Vol. 8, No. 9, Sept. 2018, E-ISSN: 2222-6990 @ 2018 HRMARS

\section{Literature Review}

Hansu (2016), constraints and issued faced by young entrepreneur in Pakistan. Data has been collected with help questionnaire and targeted population were only MBA students of final year. In this study researchers explained that unfriendly policies and environment are key problems faced by young entrepreneur in Pakistan, once these key problems would be addressed than outcomes in terms of poverty reduction and economic development among the country cannot be ignored.

Khuong \& Nguyen (2016), Impacts of individual attributes, earlier entrepreneurial experience, outside condition, social standard and perceived viability on business aim through the positive and negative perception toward entrepreneurship. The focus of this study mainly lies on entrepreneurship intention. Sample was collected from Vietnam National University (VNU) from 401 students age ranges from 18 to 24 years. In this study, it is proved that the earlier entrepreneurial experience, outside condition and perceived viability on business aim are the three important factors that affects the positive perception toward the entrepreneurship whereas individual attributes and social standards have negative impacts towards entrepreneurship. This study also has significant implications for political and educational restructuring to develop entrepreneurship in terms of quantity and quality and made the foundations for individuals to prosper as entrepreneur in future. Denanyoh et al. (2015), The most important pillar of economic expansion, productiveness and societal development is Entrepreneurship. This paper was written to find out those factors which influence on entrepreneurial intentions of technical school students. For conducting this research based study, 288 students were selected. According to this paper, intention of entrepreneurship was taken as goal of education and support from social groups. As per the outcome of this research, these factors influence of student's entrepreneurial willingness. The findings of this research will help educational policy making of Ghazza in bringing change for the betterment of students.

Harrasi et al. (2014), Entrepreneurship is an important source to improve the economy. This study helps to identify the factors impacting individuals' entrepreneurial intention and high level of significance in specifying the degree to which people are keen on beginning up a new business. This paper is concentrated on four arrangements of variables personality traits, contextual variable, motivational, and personal background. The clearest finding rises out of this investigation that personality traits factors (self-confidence, risk-taking propensity, needs for achievements, internal locus of control, innovativeness, and autonomy) are the most examined factors in the literature. This research will fill in as a base for future studies and will help researchers to consider these components while looking at the goal of people towards entrepreneurship.

Rasli et al. (2013), Factors Affecting Entrepreneurial Intention Among Graduate Students of University Technology Malaysia. This study was conducted to provide new experiences concerning this vacant gap in the "entrepreneurship" study in the period of globalization, and knowledge based-economy", where the Malaysian government has set more prominent accentuation on promoting high-growth, high-tech start-ups by highly educated professionals. Thus, there is a requirement for many entrepreneurs to be included effectively in the economic development to manage competency in the quick pace of innovation change. The assessment of entrepreneurial goal among the university students is a need to identify their level of entrepreneurial orientation. A dominant part of these students will quickly contribute more to the economic development after they graduate, not as compensation specialists but rather as business people. 
Micozzi (2013), Due to the lowest rate of entrepreneurial activity in Italy in last decade, the study was conducted to understand factors influencing entrepreneurial intentions of people in Italy and comparing them with European people. Analyst consider macro and micro economic factors, which push or pull entrepreneurs. The research finding showed that the education system of Italy doesn't have enough capacity to generate entrepreneurs.

Garaba (2012), according to him after graduation good number of students start business in small scale but due to problem faced by them, they decide to windup the business activities. In this study, he talked about of only three years student usually sticks with small scale business after that they most of time join public or private organization to secure future and to continue as an entrepreneur is very least feasible option for them.

Peng et al. (2012), Entrepreneurial Intentions and its influencing factors. In 2009, a survey was conducted in china from nine universities in which 2010 university students participated, the survey was conducted to evaluate the entrepreneurial intentions of university students and factors influencing their intentions. According to the written paper based on that survey, intentions of University students were found strong towards entrepreneurship. This paper also highlights influence of other factors on students, such as cognitive aspect, influence of family history and communal group factors.

Zain et al. (2010), The spirit of business in Malaysian business students. Survey was conducted from business undergraduate students of Malaysian Public university. The study examines whether the graduates have the spirit to do business or not after graduation. This study was conducted to determine the intensions of business graduates in beginning the business. The study focuses to determine whether the factors like environmental factors or personal attributes impact on the business graduates to pursue entrepreneurship or not. Out of total survey more than half responses were favouring personal attributes that makes impact on business graduates. According to results, personal attributes play significant role in influencing business graduates to become entrepreneur. They get influence from their family, their education, their experiences gained by observing different entrepreneurs. The finding implicates that education can play a major role in motivating students to become entrepreneurs. By introducing more knowledge through academics about merits of entrepreneurship and in turn, adding in the development of the country's economies and world-wide competitiveness.

Selcuk (2009), factor affecting entrepreneurial an intention among university students in Turkey. The Sample was consisting of 300 students and contextual factors were studied in this study, factor analysis and regression analysis techniques were used for data analysis. Results indicated that structural and educational support factors affect the intention among tertiary students for to become entrepreneur, here educational support in terms of learning of entrepreneurial skills into universities and support factors includes both personal and environmental factors were discussed. According to results universities should play their role for the growth of entrepreneur intention among university students and government can also reduce the environmental factors by designing entrepreneur friendly policies.

Kavitha Raman (2008), Motivational factors that enforce women to become entrepreneur in Malaysia. This study was based on 225 women and comparison between women entrepreneur and women non- entrepreneur. Descriptive analysis showed results those motivational factors such as 
INTERNATIONAL JOURNAL OF ACADEMIC RESEARCH IN BUSINESS AND SOCIAL SCIENCES Vol. 8, No. 9, Sept. 2018, E-ISSN: 2222-6990 @ 2018 HRMARS

work core, economic core, social core, individual core and entrepreneurial core. Based on results it is recommended that motivational and environmental factors influence major role in entrepreneurial. Katono et al. ((2008), This study investigates the relationship between social and closer valuation and intention to start a business by graduates in Uganda. this examination depended on 217, third year business understudies utilizing the recently made Entrepreneurial Intentions Questionnaire (EIQ) investigation uncovers that negative societal impression of enterprise are essential obstructions against graduate start up.

\section{Methodology}

\section{Data Source}

The data source of the study is 'Primary', which involves collection of research data directly from the respondents. In other words, primary source is the direct data source related to the subject or problem. Here, data will be collected directly from the participants using a structured adopted questionnaire based on business graduate to become entrepreneur.

\section{Population of the Study}

Population of a research study are participants or the respondents of the study that possess similar characteristics or traits Weiss (2012). As the aim of the study is to explore business graduate to become entrepreneur in Sindh province of Pakistan, therefore the population of the study consists of final year students of both private and public universities/institutes.

\section{Sampling Strategy}

In a primary research, sampling is an important component, which determines the number of respondents participating in the research study. Due to several constraints, including time, geographic and finance, it is important for a study to select a subset for the population. The sampling process can be either probability or non-probability. In this case, 'convenience sampling' technique is used, which is a form of non-probability sampling, and considers accessibility and proximity of the respondents Weiss (2012).

Table 1 University Wise Sample Size

\begin{tabular}{|c|c|}
\hline Name of University & Urban Student BBA/MBA \\
\hline University of Sindh Jamshoro & 64 \\
\hline Isra university & 32 \\
\hline Iqra University Karachi & 40 \\
\hline SZABIST Karachi & 55 \\
\hline SZABIST Hyderabad & 64 \\
\hline Muhammad Ali Jinnah University Karachi & 25 \\
\hline HIAST Hyderabad & 25 \\
\hline MUET Jamshoro & 15 \\
\hline Total number & 330 \\
\hline
\end{tabular}

\section{Sample Size}

The research study selects a sample size, as it is practically not possible to explore the entire research population, due to many limitations. In this study, to ensure an adequate sample, data was 
INTERNATIONAL JOURNAL OF ACADEMIC RESEARCH IN BUSINESS AND SOCIAL SCIENCES

Vol. 8, No. 9, Sept. 2018, E-ISSN: 2222-6990 (C) 2018 HRMARS

collected from 330 respondents. According to thumb of rule for sample size Total number $=$ (No of items in questionnaire $\times 10$ ), so $30 \times 10=300$. But in this study 30 more respondents are considered.

\section{Research Variables}

Research is the process that defines the relationship between the variables. A variable is defined as the concept that can have different quantitative values. A variable which is affected by another variable means it is a consequence of the any other variable it is called dependent variable. On the other side, the variable that cause change in the other variable is called independent variable Kothari and Gaurav (2014).

The present also study the relationship between different variables. The below describe the dependent and independent variables of the study and statistical techniques to measure the relationship between these variables.

Table 2 Hypothesis, Variables and Techniques

\begin{tabular}{|c|c|c|c|c|c|}
\hline \multirow[t]{2}{*}{ S. No } & \multirow[t]{2}{*}{ Hypothesis } & \multicolumn{2}{|c|}{ Variables } & \multirow{2}{*}{$\begin{array}{l}\text { Based on } \\
\text { objectives }\end{array}$} & \multirow[t]{2}{*}{ Technique } \\
\hline & & Independent & $\begin{array}{l}\text { Dependen } \\
\mathrm{t}\end{array}$ & & \\
\hline 1. & H1 & $\begin{array}{c}\text { (Motivation) } \\
\text { Intrinsic Rewards }\end{array}$ & BGE* & 1 & $\begin{array}{l}\text { Reliability analysis } \\
\text { Multiple regression analysis }\end{array}$ \\
\hline 2. & $\mathrm{H} 2$ & $\begin{array}{c}\text { (Motivation) } \\
\text { Extrinsic Rewards }\end{array}$ & BGE* & 1 & $\begin{array}{l}\text { Reliability analysis } \\
\text { Multiple regression analysis }\end{array}$ \\
\hline 3. & H3 & $\begin{array}{l}\text { (Motivation) } \\
\text { Autonomy }\end{array}$ & BGE* & 1 & $\begin{array}{l}\text { Reliability analysis } \\
\text { Multiple regression analysis }\end{array}$ \\
\hline 4. & H4 & $\begin{array}{l}\text { (Motivation) } \\
\text { Family security }\end{array}$ & BGE* & 1 & $\begin{array}{l}\text { Reliability analysis, } \\
\text { Multiple regression analysis }\end{array}$ \\
\hline 5. & H5 & $\begin{array}{l}\text { (Motivation) } \\
\text { Change } \\
\text { Management }\end{array}$ & $\mathrm{BGE}^{*}$ & 1 & $\begin{array}{l}\text { Reliability analysis, } \\
\text { Multiple regression analysis }\end{array}$ \\
\hline
\end{tabular}

*BGE= Business Graduates to become Entrepreneur

\section{Research Instrument}

The data source of the study is primary, and therefore data will be collected directly from the research participants with the help of 5-point Likert scale Questionnaire. Likert scale is measured as follows:

1-Strongly Disagree

2-Disagree

3-Neutral

4-Agree

5-Strongly Agree

Research instrument of the study is adopted from single source, the questionnaire is measuring various motivations and obstacles factors, business graduate to become entrepreneur. 
INTERNATIONAL JOURNAL OF ACADEMIC RESEARCH IN BUSINESS AND SOCIAL SCIENCES Vol. 8, No. 9, Sept. 2018, E-ISSN: 2222-6990 @ 2018 HRMARS

Table 3 Layout of Questionnaire

\begin{tabular}{|c|c|c|c|c|}
\hline Section & Variable & No. of items & Scale & Source \\
\hline 1. & $\begin{array}{c}\text { Entrepreneur after } \\
\text { graduation }\end{array}$ & 9 & Likert Scale & Ooi\& Ahmed (2012) \\
\hline 2. & Intrinsic reward & 6 & Likert Scale & Ooi\& Ahmed (2012) \\
\hline 3. & Extrinsic reward & 3 & Likert Scale & Ooi\& Ahmed (2012) \\
\hline 4. & Autonomy & 6 & Likert Scale & Ooi\& Ahmed (2012) \\
\hline 5. & Family security & 3 & Likert Scale & Ooi\& Ahmed (2012) \\
\hline 6. & Change Management & 3 & Likert Scale & Ooi\& Ahmed (2012) \\
\hline
\end{tabular}

\section{Research Model}

$$
I E A G=\alpha 0+\beta_{1} I R+\beta_{2} E R+\beta_{3} A+\beta_{4} F S+\beta_{5} C M+\text { eit }
$$

Whereas, entrepreneur after graduation (EAG), Intrinsic reward (IR), Extrinsic reward (ER), Autonomy (A), Extrinsic reward (ER) Change Management (CM) and error (eit)

\section{Results and Discussion}

Demographic Distribution:

\subsubsection{By Gender:}

\section{GENDER DISTRIBUTION}

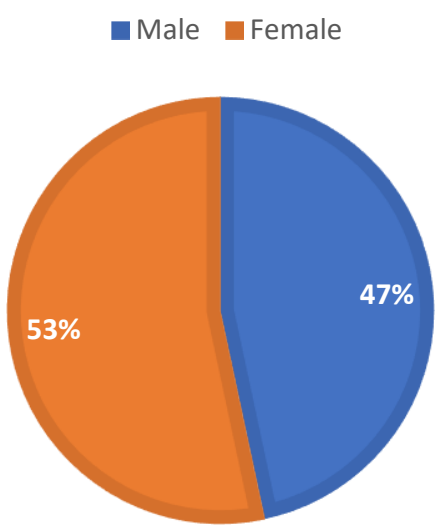

Figure 1 Demographic Distribution by gender

Figure 1 depicts that in this study out of 330 respondents $53 \%$ response were received from females whereas $47 \%$ responses were received by males. 
By Age Group:

AGE GROUP

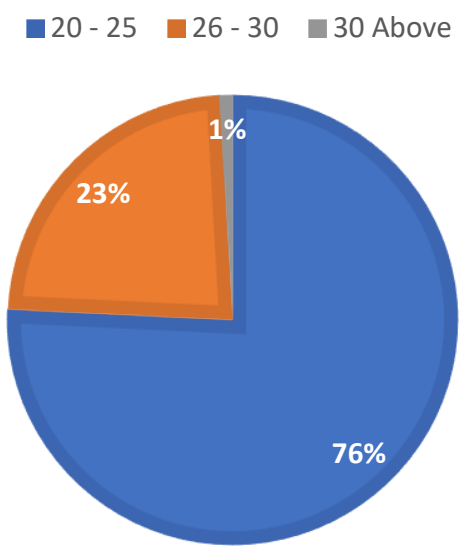

Figure 2 Demographic Distribution by age group

Figure 2 depicts that in this study out of 330 respondents $23 \%$ respondents belongs to the age group between $20-25,76 \%$ respondents belongs to the age group between $26-30$ and only $1 \%$ respondents belongs to the age group of 30 above.

\section{By Program:}

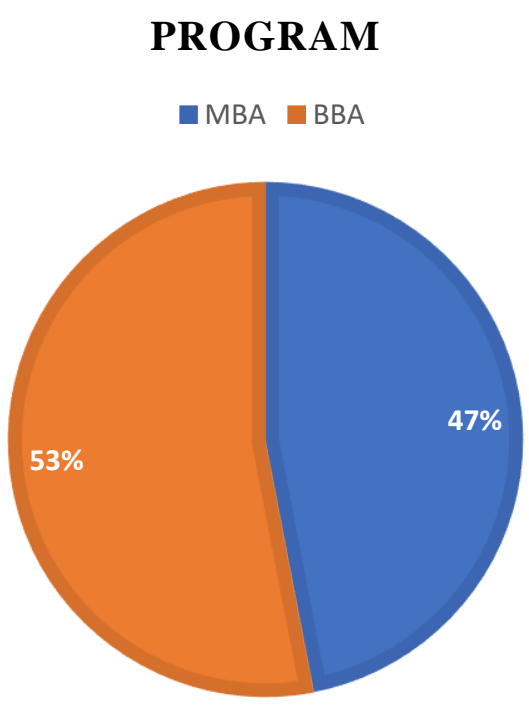

Figure 3 Demographic Distribution by program

Figure 3 depicts that in this study out of 330 respondents $53 \%$ respondents belongs to the BBA program whereas $47 \%$ respondents belongs to the MBA program. 
INTERNATIONAL JOURNAL OF ACADEMIC RESEARCH IN BUSINESS AND SOCIAL SCIENCES

Vol. 8, No. 9, Sept. 2018, E-ISSN: 2222-6990 @ 2018 HRMARS

\section{Reliability Analysis}

Table 4 Reliability Analysis of Motivation Variables

Reliability Statistics

\begin{tabular}{|l|l|l|l|}
\hline Variables (Motivation) & Cronbach's Alpha & No of Items & Remarks \\
\hline Intrinsic rewards & .882 & 30 & Excellent \\
Extrinsic Rewards & & & \\
Independence/Autonomy & & & \\
Family Security & & & \\
Change Management & & & \\
\hline
\end{tabular}

Source: Author' Estimations

You can see in above table 4 the Reliability Statistics, the value of Cronbach's Alpha is used for final decisions about reliability of studied data. On that basis, we can level of reliability in terms of poor or good, in our case Cronbach's Alpha value is $\mathbf{0 . 8 8 2}$ or $\mathbf{8 8 . 2 \%}$ is excellent, for the total number of items in the studied data set is 30 . The conclusion for reliability for the motivation variables can be drawn as data is reliable.

Multiple Regression Analysis

Table 5

Model summary

\begin{tabular}{|l|c|}
\hline \multicolumn{1}{|c|}{ Variables } & R \\
\hline Intrinsic rewards (IR) & $.633^{\mathrm{a}}$ \\
Extrinsic Rewards (ER) & \\
Independence/Autonomy (AU) & \\
Family Security (FS) & \\
Change Management (CM) & \\
\hline
\end{tabular}

Source: Author' Estimations

a. Predictors: (Constant), CM, ER, AUTONOMY, FS, IR

b. Dependent Variable: BGE

In table \#05, model summery indicates the relationship between estimated value of dependent variable and studied variables. All mentioned independent variables shows the $R$ value is in this study 63.3\%. $R$ value also indicates overall fitness of model.

\section{ANOVA}

Table 6

ANOVA

\begin{tabular}{|c|c|}
\hline Model & Sig. \\
\hline 1 Regression & $.000^{\mathrm{a}}$ \\
\hline
\end{tabular}

Source: Author' Estimations

a. Predictors: (Constant), CM, ER, AUTONOMY, FS, IR

b. Dependent Variable: BGE 
INTERNATIONAL JOURNAL OF ACADEMIC RESEARCH IN BUSINESS AND SOCIAL SCIENCES

Vol. 8, No. 9, Sept. 2018, E-ISSN: 2222-6990 @ 2018 HRMARS

Table \# 6 indicates fitness of model, in our case the value of $p$ is 0.00 which is less than 0.05 . This $p$ value concludes our studied research model is fit and we can predict the results of dependent variables with respect to independent variables.

\section{COEFFICIENT}

\section{Table 7}

Coefficient

\begin{tabular}{|c|c|c|c|}
\hline \multirow{2}{*}{ Model } & Standardized Coefficients & \multirow{2}{*}{ P value } & Collinearity Statistics \\
\cline { 2 - 2 } & Beta & .001 & VIF \\
\hline (Constant) & .429 & .000 & 2.192 \\
IR & .187 & .008 & 1.403 \\
ER & .121 & .021 & 1.477 \\
AUTONOMY & .154 & .009 & 1.856 \\
FS & -.023 & .732 & 2.494 \\
CM & & & \\
& & & \\
\hline
\end{tabular}

\section{Source: Author' Estimations}

Dependent Variable: BGE

A coefficient table shows two important values, value of beta and $p$-value. The value of beta usually determines the relationship between dependent variable with independent variables whereas $p$ value shows level of significance. We can see in this study all studied variables Intrinsic rewards (IR), Extrinsic Rewards (ER), Independence/Autonomy (AU), Family Security (FS), are found to have positive and significant relationship with dependent variable Business Graduates to become Entrepreneur (BGE) except Change Management (CM) which is having negative relationship with dependent variable. We can see that in VIF column our all studied variables have values less than 10 that indicates in our research model has no multicollinearity. In this regard, our stated results are not overestimated.

\section{Conclusion}

The main purpose of this research was to find the motivation to business graduates to become entrepreneur in Sindh, Pakistan. In this analysis authors have considered five independent variables such as intrinsic rewards, extrinsic rewards, autonomy, family security, change management's impact on dependent variable such as business graduate to become entrepreneur.

The findings of this study revealed that the all the above studied variables are found significant and positive except change management on business graduate to become entrepreneur. However, the unique finding of this study is that change management doesn't have impact to became entrepreneur due to unstable business environment in case of Sindh, Pakistan, first reason can be attitude of risk aversion. This has been practically observed that most of the business graduates prefer job over starting up their own businesses particularly due to high risk in terms of return and second reason family dependency also cannot be ignored in developing countries. 
INTERNATIONAL JOURNAL OF ACADEMIC RESEARCH IN BUSINESS AND SOCIAL SCIENCES Vol. 8, No. 9, Sept. 2018, E-ISSN: 2222-6990 @ 2018 HRMARS

\section{Contribution of Study}

In order to ensure the effective deliver of right skills as per labour market and acceptance of entrepreneurship mind set. This mind set would help two an important area with context of young people such as growth of businesses, creating a new jobs and better economic growth. The Entrepreneurship education is most accepted concept for addressing the serious many issues likewise socio-economic problems of unemployment and poverty at country level. However, this concept is misguided by the scholars. The tertiary education institutions should develop high growth for all academic disciplines such as universities and Polytechnics. This is the key reasons entrepreneurial education is the point of attention of all scholars, institutes and policy makers ever before.

\section{Recommendations}

- University Based Incubation (UBS)r centres should be developed in business higher education institutes and universities for developing business skills among business graduates.

- Workshops and trainings programs should be arranged in business higher education institutes and universities for developing risk taking attitudes among business graduates.

\section{Future Recommendations}

- This comparative analysis can further be extended in terms of gender.

- This comparative analysis can be performed in other provinces of Pakistan.

- This comparative analysis can further be studied with respect to programs such as BBA \& MBA.

- Other than business students, other graduates could participate in future research.

\section{References}

Abir S, Al-Harrasi , Eyad B, Al-Zadjali, \& Zahran S. . (2014). Factors Impacting Entrepreneurial Intention: A Literature Review. International Journal of Social, Behavioral, Educational, Economic, Business and Industrial Engineering, 08(08).

Amercian Agricultural Economics Assoication , 23-26 Richard, H. a. (n.d.). Exogenous variable.

A.S, G. (2012). Entrepreneurship, public policy and poverty reduction in Nigeria. International Journal of Business and Social Research, 158-169.

Bryman, A. \&. (2007). Business Research Methods. Oxford Univeristy Press.

Collins, L. H. (2004). Enacting entrepreneurial intent: the gaps between student needs and higher education. Education and Traning, 454-463.

Creswell, J. W. (2013). Research design: Qualiative, quantitative and mixed methods approaches. Sage publications.

Deci, R. M. (2000). Intrinsic and Extrinsic Motivations: Classic Definitions and New Directions.

Denanyoh, R., Adjei, K., \& Nyemekye, G. E. (2015). Factors That Impact on Entrepreneurial Intention of Tertiary Students in Ghana. International Journal of Business and Social Research, 05(03).

Eurobarometer. (2007). Entrepreneurship-Survey of the EU25. Denmark: European Commission.

A.S, G. (2012). Entrepreneurship, public policy and poverty reduction in Nigeria. International Journal of Business and Social Research, 158-169. 
INTERNATIONAL JOURNAL OF ACADEMIC RESEARCH IN BUSINESS AND SOCIAL SCIENCES Vol. 8, No. 9, Sept. 2018, E-ISSN: 2222-6990 @ 2018 HRMARS

Abir S, Al-Harrasi , Eyad B, Al-Zadjali, \& Zahran S. . (2014). Factors Impacting Entrepreneurial Intention: A Literature Review. International Journal of Social, Behavioral, Educational, Economic, Business and Industrial Engineering, 08(08).

Bryman, A. \&. (2007). Business Research Methods. Oxford Univeristy Press.

Collins, L. H. (2004). Enacting entrepreneurial intent: the gaps between student needs and higher education. Education and Traning, 454-463.

Creswell, J. W. (2013). Research design: Qualiative, quantitative and mixed methods approaches. Sage publications.

Deci, R. M. (2000). Intrinsic and Extrinsic Motivations: Classic Definitions and New Directions.

Denanyoh, R., Adjei, K., \& Nyemekye, G. E. (2015). Factors That Impact on Entrepreneurial Intention of Tertiary Students in Ghana. International Journal of Business and Social Research, 05(03).

Eurobarometer. (2007). Entrepreneurship-Survey of the EU25. Denmark: European Commission.

Frederick, H. (2016). Entrepreneurship: Theory/Process/Practice with Student Resource . India: Cengage Learning Australia.

Galloway, L. a. (2002). Entrepreneurship education at university: a driver in the creation of high growth firms. Education and Training, 398-405.

Gorman, G. a. (1997). Some research perspectives on entrepreneurship education, enterprise education and education for small business management. International small Business Journal , 56-78.

Hasnu, S. A. (2016). Issues and constraints perceived by young entrepreneurs of Pakistan. World Journal of Entrepreneurship, Management and Sustainable Development , 50-65.

Hazzouri, M. C. (2014). An Investigation of the Emotional Outcomes of Business Students Cheating "Biological Laws" to Achieve Academic Excellence. Academy of Management Learning \& Education, 440 - 460.

Henderson, R. a. (2000). Who wants to be an entrepreneur? Young adult attitudes to entrepreneurship as a career. Career Development International, 279-287.

Jeter, H. R. (n.d.). Family Security and National Defense.

Jin-Hyuk Ahn, S. T. (n.d.). What is change management?

Katono , I. W., Heintze , A., \& Byabashaija, W. (n.d.). Environmental factors and graduate start up in Uganda.

Kavitha Raman, A. R. (2008). Motivational Factors Affecting Entrepreneurial Decision: A Comparison between Malaysian Women Entrepreneurs and Women Non Entrepreneurs. Communications of the IBIMA.

Kelly, D. B. (2010). Global Entrepreneurship Monitor, Global Report. USA: GEM.

Khuong , M. N., \& Nguyen, A. H. (2016, February). The Factors Affecting Entrepreneurial Intention of the Students of Vietnam National University- A Mediation Analysis of Perception toward Entrepreneurship. Journal of Economics, Business and Management, 04(02).

Kolvereid, L. a. (1997). Entrepreneurship among business graduates:does a major in entrepreneurship make a differnce. Journal of European Industrial Training, 154-60.

Kuratko, D. (2005). The Emergence of Entrepreneurship Education: Development, Trends, and Challenges. Entrepreneurship Theory and Practice, 577-598.

Mack, N. W. (2005). Qualitative research methods: a data collector's field guide. 
INTERNATIONAL JOURNAL OF ACADEMIC RESEARCH IN BUSINESS AND SOCIAL SCIENCES

Vol. 8, No. 9, Sept. 2018, E-ISSN: 2222-6990 @ 2018 HRMARS

Marshall, M. I. (2006). The effect of Human and Financial Capital on the Entrepreneurial Process. Amercian Agricultural Economics Assoication , 23-26.

McCrea, E. (2010). Integrating Service-Learning into an Introduction to Entrepreneurship Course. Journal of Management Education,, 39-61.

Micozzi, A. (2013, June). Factors affecting the entrepreneurial dynamics in Italy: a comparison across European countries. Economia Marche Journal of Applied Economics, XXXII(01).

Murnieks, C. e. (2014). Pathways of Passion: Identity Centrality, Passion, and Behaviour. Journal of Management, 1583 - 1606.

Mustafa, I. \&. (2003). Small \& Medium Enterprises in Pakistan. South Asian Journal.

Nielsen, E. (2006). Endogenous. Jargon Alert.

Paiva, V. L. (n.d.). The complex nature of autonomy.

Peng, Z., Lu, G., \& Kang , H. (2012). Entrepreneurial Intentions and Its Influencing Factors: A Survey of the University Students in Xi'an China. Creative Education, 03.

Poh kam Wong, Y. p. (2005). Entrepreneurship, Innovation and Economic Growth: Evidence from GEM data. Small Business Economic, 335-350.

Rasli, A., Khan, S.-u.-R., \& Malekifar, S. (2013, February). Factors Affecting Entrepreneurial Intention Among Graduate Students of Universiti Teknologi Malaysia. Research Gate.

Reynolds. (1987). New firms societal contribution vervus survival potential. Journal of Business Venturing, 231-246.

Richard, H. a. (n.d.). Exogenous variable.

Rolf, S. (2009). Regional Dimensions of Entrepreneurship . Foundations and Trends in Entrepreneurship, 211-340.

Selcuk, D. T. (2009). Which factors effect entrepreneurial intention of univeristy students? . Journal of European Industrial Training, 142-159.

Sophia Stathopoulou, D. P. (2004). Rural Entrepreneurship in Europe: A Research framework and agenda. International Journal of Entrepreneurial Behavior \& Research, 404-425.

Venkatarama, S. S. (2000). The Promise of Entrepreneurship as a field of research. Academy ol Managemenl fleview, 25.

Weiss, N. A. (2012). Introductory Statistics. Pearson Education.

Zahra. (1999). The challenging rules of global competitiveness in the 21st century. Academy of Management Executive, 36-42.

Zain, Z. M., Akram, A. M., \& Erlane . (2010). Entrepreneurship Intention Among Malaysian Business Students. CANADIAN SOCIAL SCIENCE, 06, 34-44. 